Federal Reserve Bank of Minneapolis

\title{
Quarterly Review
}

After Keynesian Macroeconomics (p. 1)

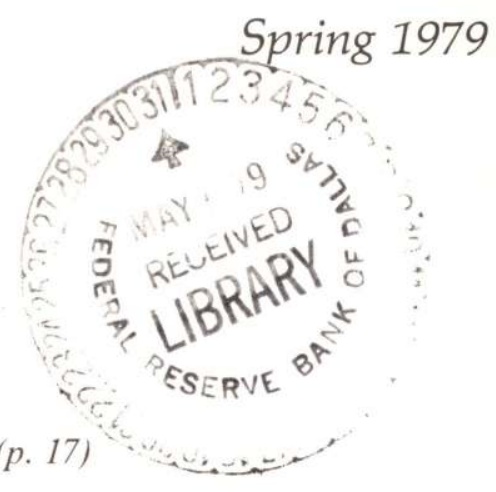

A Cloudy Future for Minnesota's Businesses (p. 17)

District Conditions (p. 24) 


\section{Federal Reserve Bank of Minneapolis}

\section{Quarterly Review vol. 3, No. 2}

This publication primarily presents economic research aimed at improving policymaking by the Federal Reserve System and other governmental authorities.

Produced in the Research Department. Edited by Arthur J. Rolnick, Kathleen S. Rolfe, and Alan Struthers, Jr. Graphic design by Phil Swenson and charts drawn by Mary K. Steffenhagen, Graphic Services Department.

Address requests for additional copies to the Research Department, Federal Reserve Bank, Minneapolis, Minnesota 55480.

Articles may be reprinted if the source is credited and the Research Department is provided with copies of reprints.
The views expressed herein are those of the authors and not necessarily those of the Federal Reserve Bank of Minneapolis or the Federal Reserve System. 


\title{
A Cloudy Future for Minnesota's Businesses
}

\author{
David S. Dahl
}

Regional Economic Affairs Specialist

Research Department

Federal Reserve Bank of Minneapolis

Over the past year, Minnesota has been witnessing a heated debate about its business climate. Some people have argued that its business climate must be good because its economy has been so prosperous in recent years. The state has indeed been relatively prosperous. It has enjoyed strong economic growth, for example. Its total wage and salary employment grew at a compound annual rate of 2.8 percent from 1969 to 1978 , much faster than employment grew in the nation as a whole, although not outstanding in relation to the surrounding states. Minnesota grew faster than the neighboring states of Iowa and Wisconsin but slower than North and South Dakota, states that had extremely rapid growth.

Because of its strong economic growth, Minnesota has experienced few serious economic problems. It has had a very low unemployment rate. In 1978 , only about 4 percent of its labor force was jobless-about average for the region but far below the nation's 6 percent. Also because of its rapid economic growth, Minnesota has had a comfortable standard of living. Its per capita personal income, according to 1977 figures, is now slightly above the national average and above that of all the surrounding states. Such current data seem to support those who believe that Minnesota's business climate is good.

Others point out, however, that Minnesota's past and present prosperity is no guarantee of future prosperity. Its past and present prosperity is a product of earlier economic decisions, decisions based on an earlier and possibly quite different business climate. Its future prosperity depends on its present and future business climate, because businesses obviously are concerned about present and future opportunities, not past ones.
A state's business climate, by definition, includes all the things that affect businesses' opportunities to grow and prosper. State and local taxes and public services are often key elements of the business climate. When a firm is picking a broad region of the country, it considers access to market and to production inputs like raw materials. To pick a particular state or community, though, it considers the other costs and benefits of the location. Many of these are influenced by state and local governments-specifically by their taxes and public services.

Taxes and public services are also key elements of the business climate because, unlike the weather or natural resources, they are the result of human decisions and can be changed directly by governmental action. They are the elements of the business climate that state and local policymakers have the most control of.

To evaluate Minnesota's business climate, therefore, one needs to consider the costs and benefits of the state's public services, both current and future, and the ways the state's businesses are dealing with them. This is a difficult task. Although this study does not pretend to be definitive, its results suggest that Minnesota's business climate is developing some problems. Its business climate is not as attractive as it was in the 1960s, and the four surrounding statesWisconsin, Iowa, South Dakota, and North Dakotanow appear to have more appeal to businesses.

\section{Methodology}

Because time intervals can be chosen to justify different conclusions, this study of the business climate in and around Minnesota has used periods of several 
years, each beginning and ending as much as possible at a similar point in the business cycle. This helps to assure that the economic changes that occurred were significant and not just the result of the usual ups and downs of the economy.

In most cases, the periods from 1960 to 1969 and from 1969 to 1978 were used for comparison, but the data were not always available for the years 1977 and 1978. Consequently, for some comparisons both periods were shortened by two years; specifically, the periods from 1962 to 1969 and from 1969 to 1976 were substituted for the longer periods. However, there is no reason to suppose that the conclusions would change with more recent data.

In this study, manufacturing receives an emphasis that at first glance might seem too heavy. Manufacturing accounts for only 20 percent of Minnesota's economic activity, but it is extremely important. It has been a big source of new jobs within the state, particularly in the 1960s. Also, it is a basic industry, one that serves primarily regional, national, and international markets, not merely local ones. Growth in such industries is essential for growth in the state's economy because it provides the wherewithal for local industries to expand. Moreover, manufacturing is a good indicator because it has more mobility than many of Minnesota's other basic industries, such as mining and agriculture. Although some manufacturers are constrained to particular localities, many could move to any of the states in this study. Growth in manufacturing is thus a fairly clear response to the business climate.

This study does not get into the subtle question of the distribution of taxes and public services within state boundaries. A preliminary look suggests that Minnesota businesses contribute about the same percentage to state and local treasuries and receive about the same percentage of public services as the businesses of other states. The matter of distribution would probably be important if the total taxes and services businesses paid and received were more equal in Minnesota and the surrounding states. But in most cases they are not even close. Thus, examining the distribution is not necessary to explain business behavior. Since this study does not examine the distribution of taxes and public services in any detail, it makes no recommendations on whether any specific taxes or public services should be changed.
The costs of doing business are higher and rising faster in Minnesota than in the rest of the region.

State and Local Government Tax Effort in Minnesota, Surrounding States, and U.S.

State and Local Taxes* per $\$ 1,000$ Personal Income Received in

\begin{tabular}{lrrr}
\hline & 1962 & 1969 & 1976 \\
\hline Wisconsin & $\$ 125$ & $\$ 146$ & $\$ 144$ \\
South Dakota & 107 & 133 & 123 \\
lowa & 111 & 125 & 120 \\
Minnesota & 121 & 125 & 147 \\
North Dakota & 96 & 125 & 118 \\
U.S. Median & $\$ 101$ & $\$ 114$ & $\$ 120$
\end{tabular}

${ }^{\star}$ Taxes collected from July 1 of this year through June 30 of the next year. Source: U.S Department of Commerce, Bureau of the Census

Changes in State and Local Government Tax Effort in U.S., Minnesota, and Surrounding States Percentage Changes in State and Local Taxes per \$1,000 Personal Income

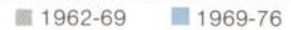

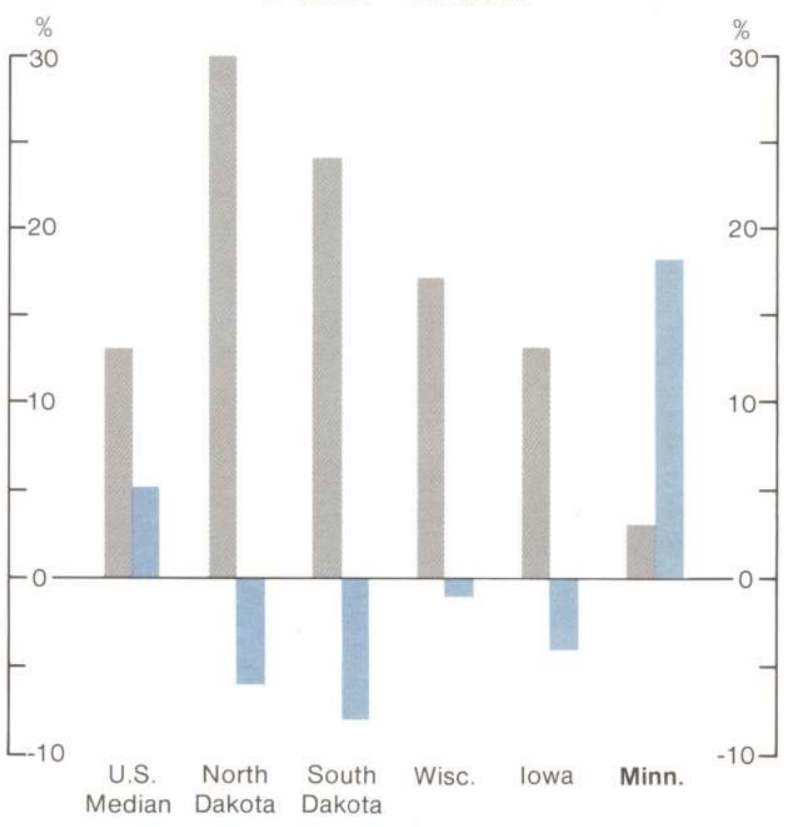

Source: U.S. Department of Commerce, Bureau of the Census 


\section{Measures of the Business Climate}

\section{Taxes}

One standard indicator of the business climate is called tax effort. A state's tax effort is the amount of its income that is going to pay for state and local public services. This is a better indicator than, say, taxes per person because it relates taxes to income or ability to pay. A commonly used measure of tax effort is the amount of state and local taxes per $\$ 1,000$ of personal income received. This is the measure used in this study. ${ }^{\prime}$

In the 1960s, Minnesota's tax effort compared favorably to that of neighboring states and to the national average. During this period it rose, but state and local tax efforts generally rose in the region and around the nation in this decade. Minnesota's increase was the smallest in the region, and its tax effort was not unusually high.

However, this changed in the 1970s. From 1969 to 1976, the states surrounding Minnesota decreased their tax efforts while Minnesota increased its effort substantially. ${ }^{2}$ In 1976, the latest year for which data are available, Minnesota had the region's highest and fastest rising tax effort.

\section{Public Services}

But businesses don't judge state and local governments by their taxes alone. Minnesota's taxes, for instance, provide a high level of public services and pay for many things that businesses need and want. The state spends more per person and more per dollar of personal income than neighboring states. Its outlays are well above the national median. Furthermore, Minnesota has become well known as a state with an excellent education system, an item that accounts for close to 40 percent of its state and local government expenses. Although Minnesota and its surrounding states generally spend more on education and other public services than most other states in the nation, Minnesota's outlays are the highest in the fivestate region.

However, while Minnesota's greater state and local government outlays may enable it to provide better public services than neighboring states, its business climate is not necessarily better. The important thing is not that residents and businesses receive more or better services. What matters is whether or not they want these services more than what they
. and although Minnesota's benefits also are greater ...

State and Local Government Spending

in Minnesota, Surrounding States, and U.S. in Fiscal 1977

\begin{tabular}{lrc} 
& Per Person & $\begin{array}{c}\text { Per } \$ 1,000 \\
\text { Personal Income }\end{array}$ \\
\hline Minnesota & $\mathbf{\$ 1 , 4 6 0}$ & $\mathbf{\$ 2 3 7}$ \\
Wisconsin & 1,322 & 218 \\
North Dakota & 1,308 & 227 \\
lowa & 1,235 & 198 \\
South Dakota & 1,180 & 232 \\
U.S. Median & $\$ 1,201$ & $\$ 205$
\end{tabular}

Source: U.S. Department of Commerce, Bureau of the Census

could buy privately with the same money. What matters is whether or not they want the services they are getting at the price they are paying. The important issue, in other words, is how people value public services.

\section{Responses to the Business Climate}

If the amount of taxes in Minnesota has seriously increased costs for businesses without providing desired public services, then we would expect to find certain patterns of business behavior. We would expect to find that Minnesota's businesses expanded more during the 1960s when the tax effort was relatively low than during the 1970 s when it was relatively high. We would also expect to find that in the 1970 s businesses that are mobile enough would choose to locate in Minnesota's neighboring states where taxes were lower. This is exactly what we do find. ${ }^{3}$

'This tax effort measure does not include unemployment and workers' compensation premiums.

${ }^{2}$ Shifting the time periods would alter some of these figures but would not change the basic point: Minnesota's tax effort is no longer in line with the tax efforts of the surrounding states, with the possible exception of Wisconsin. The Advisory Commission on Intergovernmental Relations reached a similar conclusion in its study of the period from 1964 to 1975. It classified Minnesota's tax effort as high and rising. Wisconsin's as high and falling, and Iowa's. North Dakota's. and South Dakota's as low and falling. See Measuring the Fiscal "Blood Pressure" of the States. 1964-1975. M-111. Advisory Commission on Intergovernmental Relations. Washington. D.C.. February 1977, p. 6.

${ }^{3}$ From here on we are emphasizing that the changes in business Continued on next page 
.... many firms seem to prefer other states.

Minnesota is losing new jobs to them...

... as well as capital spending . .

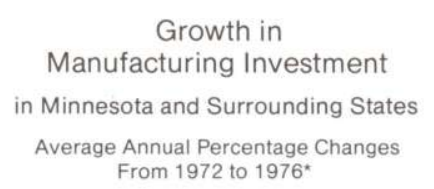

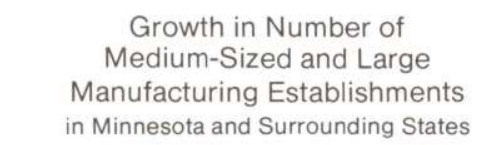

Percentage Changes $1962-69 \quad$ in $1969-76$

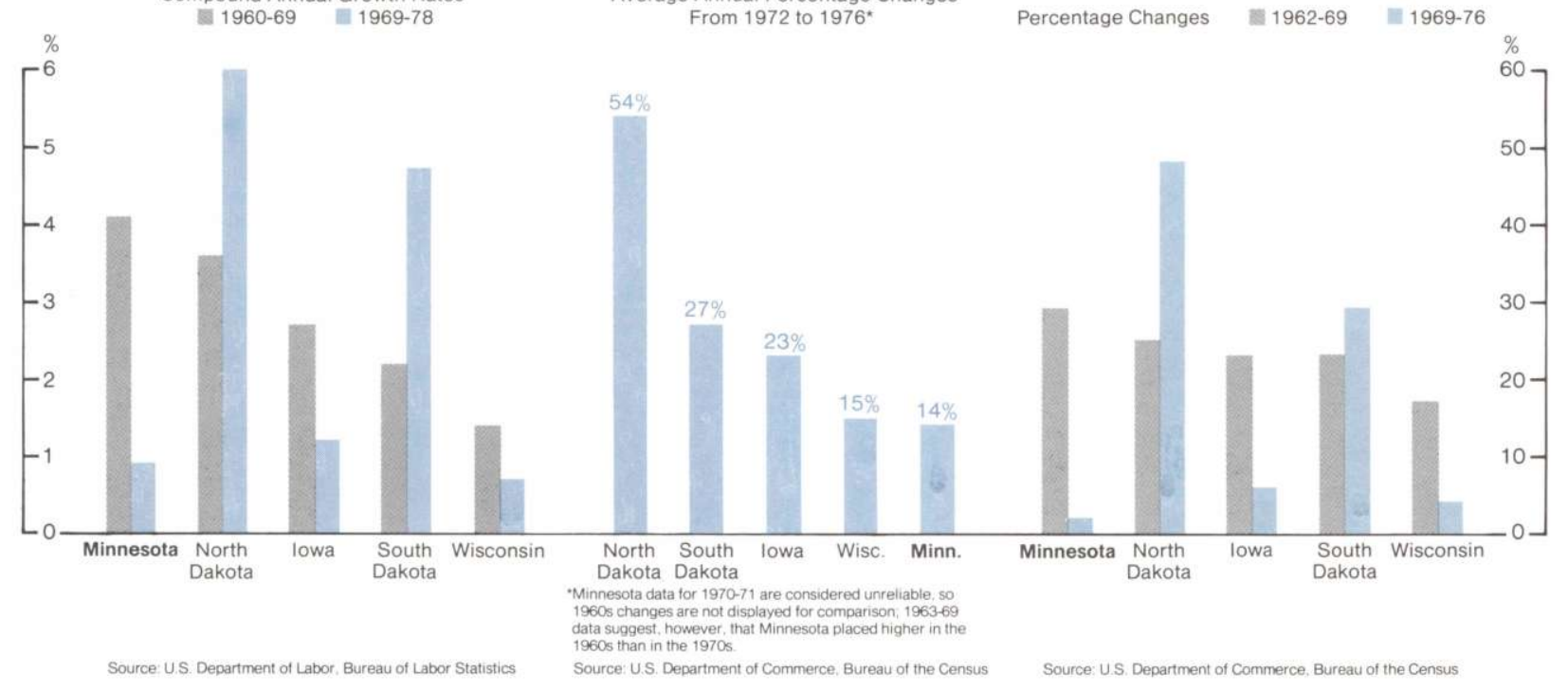

\section{Employment}

Employment is a good indicator of private responses to the business climate. When employment grows in an area or an industry, it indicates that existing firms have done well enough to add to their work forces, that new firms have been attracted to the market, or both. While total wage and salary employment has grown well in Minnesota in general, a more detailed look at employment suggests that the state is becoming less attractive to businesses. From 1960 to 1969, Minnesota's growth rate in manufacturing employment was faster than that of the surrounding states. But this fell off markedly from 1969 to 1978. Its growth in manufacturing employment has become one of the slowest in the five-state region.

Granted, it does not take much of a gain in manufacturing jobs in states like North and South Dakota to generate a large percentage increase, since these states have small manufacturing industries to begin with. The combined economies of the Dakotas and Iowa approximate the size of Minnesota's economy and provide a check on the results of the state-bystate comparison. But the results of this comparison are not much different. During the 1960s, Minnesota gained 49,000 more manufacturing jobs than these three states combined, but in the 1970s it gained 13,000 fewer. That is, Minnesota's manufacturing employment grew 4 percent in the earlier period but less than 1 percent in the most recent period, while manufacturing employment in the three combined states grew 2.7 percent and then 1.6 percent. Businesses now seem to find the other states in the region more attractive than Minnesota.

activity reflect geographical movement-businesses choosing to move old plants or locate new plants outside Minnesota. Most of these changes, of course, also reflect the slower production growth of businesses still in Minnesota. 
An examination of employment patterns along Minnesota's borders leads to the same conclusions. Businesses that settle or expand near a border can choose to do so in Minnesota or another state just by moving a few miles. Wherever they decide to locate, they will have almost identical labor pools, transportation costs, and access to raw materials and markets. Thus, a business on a border can choose one state over another with few concerns other than the business climate.

Businesses frequently are not choosing Minnesota. In the Minnesota counties on the western border, employment in all industries grew 25 percent between 1969 and 1976, the period during which Minnesota's tax effort increased so sharply. ${ }^{4}$ But a few miles away, in the North and South Dakota counties adjacent to Minnesota, employment grew 40 percent, more than half again as fast. In the Minnesota counties on the southern border, employment grew 15 percent in this period. But a few miles away, in Iowa, employment grew 36 percent. Along the eastern border, Minnesota's growth in employment was close to Wisconsin's, mainly because of strong growth on the outskirts of the Twin Cities. Along all three borders, total employment grew 10 percentage points slower in Minnesota counties than in adjacent counties in neighboring states. Clearly, many businesses that might have located in Minnesota in recent years chose to do so in other states. For comparison, from 1962 to 1969 Minnesota's employment growth in border counties was faster than in recent years and stronger when compared to the surrounding states'.

The differences between Minnesota and the surrounding states are even more pronounced in manufacturing employment. The growth in this type of employment in Minnesota's border counties did not even come close to that in the adjacent counties in surrounding states. Minnesota actually lost jobs on all but the western border-and here the growth rate of North and South Dakota was almost three times Minnesota's. In all, manufacturing employment grew 32 percent in the counties outside of Minnesota, while within the state it shrank 3 percent. In the 1960s, in contrast, Minnesota's border counties' growth in manufacturing was faster and compared more favorably to the growth in manufacturing in the counties adjacent to Minnesota. Once again, the evidence says that manufacturing firms found Minne- sota uncongenial in recent years.

\section{Investment Spending}

Employment gives us a yardstick of current business behavior, but to see what future business behavior might be it is necessary to examine business investment spending. This is important because when a business invests in a new plant or new equipment, it expects to stay in the same location for several years. A broad indicator of business investment is the number of nonresidential contracts - contracts for commercial, industrial, and public buildings - that are awarded. These contracts indicate something about the future economy, since new facilities are needed for long-term economic growth.

According to these data, businesses have not been favoring Minnesota when planning. From 1960 to 1969 , the average annual rate of increase in nonresidential contract awards was 9 percent in this state, higher than it was in all of the surrounding states except Iowa. But from 1969 to 1978, its growth fell to 8 percent, making Minnesota and Wisconsin the lowest states in the region. ${ }^{5}$

This pattern reappears when the investment most responsive to the business climate, such as manufacturing investment, is isolated. In recent years, capital spending by Minnesota's manufacturers has not kept pace with neighboring states'. From 1972 to $1976,{ }^{6}$ Minnesota's manufacturing investment rose 14 percent, essentially matching Wisconsin's 15 percent but considerably below the advances of Iowa and the Dakotas.

Nonresidential contracts and manufacturing investment are useful yardsticks of business spending, but they only measure new development. And, of course, some of this new development is to replace obsolete structures or equipment. To get some idea of net growth, therefore, it is necessary to compare the number of manufacturing plants in operation on certain dates. It is reasonable to count only those

\footnotetext{
${ }^{4}$ This employment measure does not include agricultural, domestic service, government, and railroad workers.

${ }^{5}$ Data provided by the F. W. Dodge Division of the McGraw-Hill Information Systems Company.

${ }^{6}$ Because of unreliable Minnesota data for 1970 and 1971 , this series was not compared to the 1960s. However, data for 1963 through 1969 suggest that Minnesota's manufacturing investment, relative to the surrounding states', grew faster in the 1960 s than in the $1970 \mathrm{~s}$.
} 
Recent job growth along Minnesota's borders indicates that businesses are

settling and expanding more in other states.

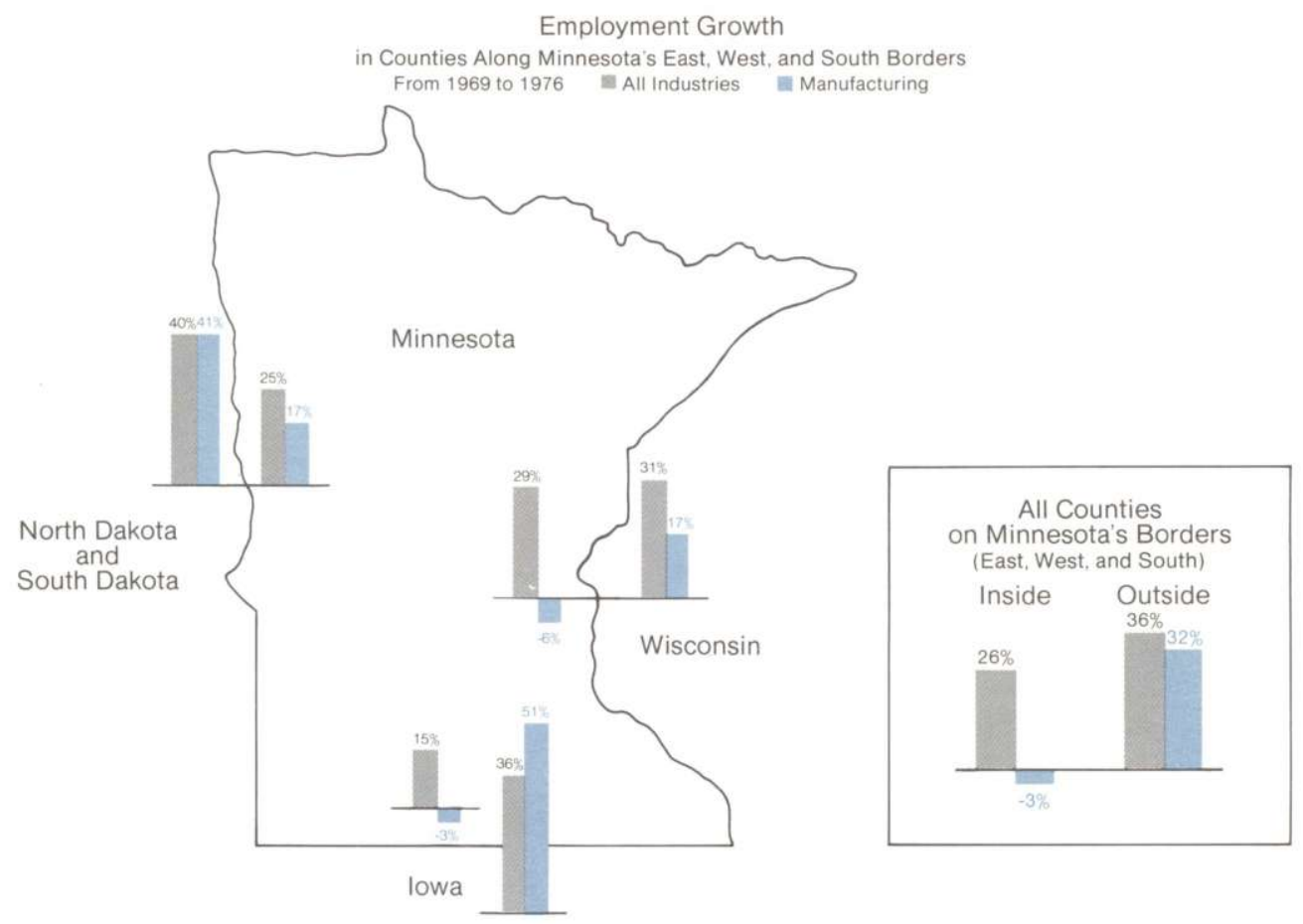

Source: U.S. Department of Commerce, Bureau of the Census

establishments that employ 20 or more people, because the location decisions of the smaller establishments like small bakeries, print shops, and sales offices are generally much more sensitive to local demand for their products than to differences in taxes between states.

When these manufacturing establishments are counted, the data fall into the pattern that is by now familiar: Minnesota looks strong in the 1960s and weak in the 1970s. From 1962 to 1969, Minnesota gained 434 large and medium-sized plants, more than any of the surrounding states. In percentage terms, it also had the largest increase in such plants. From 1969 to 1976, though, Minnesota dropped almost to the bottom. It gained only 42 new establishments, one more than South Dakota, the state that gained the fewest plants in the region. In percentage terms, Minnesota had the smallest increase -2 percentwhile the surrounding states grew from 4 to 48 percent.

\section{Conclusions}

It is clear that Minnesota has a higher tax effort than the surrounding states and that its taxes are higher now than they were in the 1960 s. It is also clear that

'If manufacturing establishments with from 1 to 19 employees are included, Minnesota's relative growth was surpassed only by North Dakota in the 1960s and by North and South Dakota in the 1970s. In terms of absolute numbers of establishments. Minnesota had the greatest growth in both periods. 
Minnesota spends more on public services than the surrounding states; its services should be correspondingly better.

All the indicators in this study, however, are consistent with the hypothesis that businesses are reacting negatively to Minnesota's high taxes, regardless of the state's high level of public services. They seem to be reducing their costs by settling or expanding in other states. Manufacturing employment is growing slower in the state now than during the 1960s, when taxes were lower. It is growing slower in Minnesota than in the surrounding states, where taxes are lower. Business investment spending is also growing slower in the state now than in the 1960s, although it has grown rapidly in most of the surrounding states. Again, this trend is particularly clear in the mobile manufacturing industry. One can thus infer that the state's business climate is not as good as it used to be and not as good as the business climates of nearby states.

Although it seems likely that Minnesota's high taxes and public services are a major cause of the trend this study has identified, one cannot be absolutely certain that they are the only cause. Businesses consider taxes and public services when making economic decisions, but they also consider other elements of the business climate-those determined by the private sector, by nature, or by circumstance.

In spite of the trend away from Minnesota, nothing in these findings suggests that Minnesota should not remain prosperous in the early 1980s. But these findings do raise concerns about later in the decade. If the public elements in Minnesota's business climate remain unattractive compared to those of the surrounding states, the shift away from Minnesota will probably continue and could accelerate. The decisions businesses are making today-decisions to stay or move, to build or not build-will affect the state's prosperity in five, ten, or fifteen years. Businesses are facing a cloudy future in Minnesota: uncertain and at least a little unattractive in comparison to neighboring states. Policymakers thus need to be concerned about the competition of these states if they want businesses to stay in Minnesota and contribute to its continuing prosperity.

This apparently means lowering tax rates. It may also require lowering expenditures on public services, although they may not have to be lowered if Minne- sota's economy keeps growing, as it probably will for the next few years. In the long run, however, if Minnesota's manufacturing employment and business investment spending continue to weaken, the state's growth could slow so much that any cut in taxes would require a heavy cut in services. This could make the necessary adjustments much harder. To avoid this, taxes apparently should be loweredand before too long. If the public elements of its business climate were brought back in line with those of the surrounding states, there would be no reason Minnesota couldn't once again grow as fast as the rest of the region. 